\title{
Measurements of organic trace gases including oxygenated volatile organic compounds at the high alpine site Jungfraujoch (Switzerland): Seasonal variation and source allocations
}

\author{
Geir Legreid, ${ }^{1}$ Doris Folini, ${ }^{1}$ Johannes Staehelin, ${ }^{2}$ Jacob Balzani Lööv, ${ }^{2}$ \\ Martin Steinbacher, ${ }^{1}$ and Stefan Reimann ${ }^{1}$ \\ Received 13 March 2007; revised 13 June 2007; accepted 21 November 2007; published 7 March 2008.
}

[1] At the high alpine site Jungfraujoch (Switzerland) mixing ratios of 21 oxygenated volatile organic compounds (OVOCs) and selected nonmethane hydrocarbons (NMHCs) have been measured by a newly developed two-stage double adsorbent system coupled to a gas chromatograph-mass spectrometer (GC-MS). In addition, formaldehyde was measured by the Hantzsch technique. Four measurement campaigns were performed once every season in 2005, providing for the first time a unique data set of OVOCs in the free troposphere of central Europe. The dominating OVOCs measured were acetone, methanol, formaldehyde and acetaldehyde, with mean mixing ratios of $622-867 \mathrm{ppt}$, $362-790 \mathrm{ppt}, 303-505 \mathrm{ppt}$ and 310-392 ppt, respectively. These compounds explained $95 \%$ of the measured organic compounds in summer and $83 \%$ in fall. Elevated mixing ratios in summer were observed for compounds with strong biogenic sources (e.g., methanol and acetone), whereas mainly anthropogenic compounds (e.g., ethanol and benzene) had higher mixing ratios during winter. Potential European source regions were estimated for the organic trace gases by combining the measured data with a statistical trajectory model. Northern Italy, southern France and southern and eastern Germany were identified as the main European contributors to the measured organic compounds at Jungfraujoch.

Citation: Legreid, G., D. Folini, J. Staehelin, J. Balzani Lööv, M. Steinbacher, and S. Reimann (2008), Measurements of organic trace gases including oxygenated volatile organic compounds at the high alpine site Jungfraujoch (Switzerland): Seasonal variation and source allocations, J. Geophys. Res., 113, D05307, doi:10.1029/2007JD008653.

\section{Introduction}

[2] The high alpine site Jungfraujoch (Switzerland) is located in central Europe at $3580 \mathrm{~m}$ asl, and is an excellent location for studying atmospheric chemical processes related to the European boundary layer and the background troposphere [Reimann et al., 2004; Zellweger et al., 2003]. Oxygenated volatile organic compounds (OVOCs) play a key role in tropospheric photochemistry as both precursors and intermediates in tropospheric production of ozone and other photo oxidants. [Atkinson, 2000; Wennberg et al., 1998]. OVOCs originate from both direct emissions by biogenic and anthropogenic sources, and secondary production from the oxidation of methane and nonmethane hydrocarbons (NMHCs). Apart from weekly measurements of $\mathrm{C}_{1}-\mathrm{C}_{4}$ aldehydes at 5 remote rural European stations since 1992/1993 [Solberg et al., 1996] and measurements of

\footnotetext{
${ }^{1}$ Laboratory for Air Pollution and Environmental Technology, Swiss Federal Laboratories for Materials Testing and Research (EMPA), Duebendorf, Switzerland.

${ }^{2}$ Institute for Atmospheric and Climate Science, Swiss Federal Institute of Technology, Zurich, Switzerland.

Copyright 2008 by the American Geophysical Union. 0148-0227/08/2007JD008653\$09.00
}

acetone and methanol at a rural site in USA during 1 year [Schade and Goldstein, 2006], measurements of OVOCs in the background troposphere have only been reported from few temporally limited campaigns. In summer 2002, Lewis et al. [2005] reported acetone, methanol, acetaldehyde and several NMHC mixing ratios in North Atlantic air, and found that the three OVOCs explained up to $85 \%$ of the total NMHCs mass under maritime conditions. Singh et al. [2000] measured selected OVOCs in the troposphere and lower stratosphere over the Atlantic during an aircraft campaign and concluded that OVOCs are important sources of atmospheric free radicals and are also linked to free tropospheric ozone formation. OVOCs were also measured during the ALERT2000 field campaign in the high Artic, where unexpectedly high mixing ratios of acetone, methanol and acetaldehyde were found [Boudries et al., 2002]. These compounds accounted for about $90 \%$ of the OVOCs in the Arctic troposphere, with photochemical production in the snow layer as a suspected main source. Furthermore, Wisthaler et al. [2002] measured methanol, acetaldehyde and acetone with proton reaction transfer-mass spectrometer (PTR-MS) over the Indian Ocean during INDOEX in 1999. High mixing ratios of methanol were discovered in biomass burning plumes, whereas acetaldehyde and acetone were elevated in air masses with high anthropogenic input. 
In addition, OVOCs were measured in marine boundary layer air at Trinidad Head, California [Millet et al., 2004], and height profiles of several OVOCs were reported from measurements over the Pacific in 2001 [Singh et al., 2004]. In the Alps measurements have been performed at the alpine background site of Sonnblick (Austria) [Karl et al., 2001a, 2001b]. In the higher troposphere over Europe Colomb et al. [2006] presented measurements of formaldehyde, methanol, acetone and toluene at 6-13 km altitude in summer. At $6 \mathrm{~km}$ altitude the mean mixing ratios reported were about $100 \mathrm{ppt}$ for formaldehyde, $800 \mathrm{ppt}$ for methanol, $1300 \mathrm{ppt}$ for acetone and $50 \mathrm{ppt}$ for toluene.

[3] In this study continuous state-of-the-art measurements of 21 OVOCs and selected NMHCs are presented from a remote location in Europe, performed during 4 seasonal campaigns lasting about 1 month each. In the following section a brief description of the instrument for measuring the OVOCs is given. This is followed by an explanation of the applied technique for separation of air masses into background conditions and periods when the station was influenced by the polluted boundary layer. In addition, the method for statistical trajectory analysis used for the source allocation is summarized. In section 3 the seasonal variations are discussed and case studies are presented, which show characteristics for the free tropospheric conditions at this high-altitude central European site. Furthermore, European sources are allocated by analyzing the measurements with trajectory analysis.

\section{Measurements and Methods}

\subsection{Trace Gas Measurements}

[4] The high alpine station Jungfraujoch $\left(46^{\circ} 33^{\prime} \mathrm{N}\right.$, $7^{\circ} 59^{\prime} \mathrm{E}, 3580 \mathrm{~m}$ asl) is located on a mountain saddle between the Jungfrau (4158 m asl) in the west and Moench (4099 m asl) in the east. The sampling point located at the top of the mountain ridge was used for the measurements of OVOCs, NMHCs and other trace gases measured by the Swiss Network for Air Pollution Monitoring (NABEL). From the heated inlet $\left(10^{\circ} \mathrm{C}\right) \mathrm{a}^{1} / 4^{\prime \prime} \times 12 \mathrm{~m}$ PFA line was used as connection to the main sampling pump of the instrument, which was run at a flow of $500 \mathrm{ml} / \mathrm{min}$. In order to avoid artifact formation of aldehydes by ozone during sampling, NO titration was used in the summer and autumn campaigns for ozone destruction [Komenda et al., 2003] with $10 \mathrm{ml} / \mathrm{min}$ of 20 ppm $\mathrm{NO}$ in $\mathrm{N}_{2}$. The produced $\mathrm{NO}_{2}$ can be seen as nonreactive on the timescale of $0.5 \mathrm{~min}$ (i.e., the time which the air was in the sampling line). From the main sampling line a $1 / 4^{\prime \prime} \times 0.5 \mathrm{~m}$ PFA line was connected to the sampling unit. The flow from this line was kept at $40 \mathrm{ml} / \mathrm{min}$ and the sample was collected for $12 \mathrm{~min}$, which resulted in a total sample volume of $480 \mathrm{ml}$. The frequency was about one sample every $50 \mathrm{~min}$.

[5] The air samples were collected on a two-stage adsorbent system connected to a gas chromatograph-mass spectrometer (GC-MS Agilent HP 6890-HP 5973N). In short, the analytes were sampled on a mainly hydrophobic adsorbent $0.6 \mathrm{~g}$ Hayesep-D trap at room temperature. By this procedure most of the water was not trapped. The rest humidity was removed from the adsorbent by dry helium flushing. The analytes were then released by heating the trap to $160^{\circ} \mathrm{C}$ and they were refocused on a $14 \mathrm{mg}$ Hayesep D trap $\left(-40^{\circ} \mathrm{C}\right)$ to ensure good separation on the GC column. For further details, see Legreid et al. [2007]. The OVOC were measured with an accuracy of 3-25\% (n-butanol: $37 \%$ ) and a precision of $1-5 \%$, calculated from intercomparison experiments. This intercomparison was a part of the European project ACCENT, subgroup Quality Assurance (QA). Methanol was only recovered at $60 \%$, and this was corrected for in the measurement campaigns. The detection limit for each compound was calculated as 3 times the standard deviation above noise of 5 zero air samples. Calibration of the instrument was performed once per day by analysis of a standard gas mixture (Apel \& Riemer Environmental Inc., USA).

[6] The OVOC system was in operation during four measurement campaigns in winter, spring, summer and autumn 2005. The winter measurements were performed from 8 February until 8 March 2005 during CLACE-4 (Cloud and Aerosol Characterization Experiment in the Free Troposphere), a campaign which was focused on ice cloud formation. Spring measurements followed from 22 April until 30 May, summer measurements from 5 August until 19 September and fall measurements from 14 October until 1 November. A total of about 2400 samples were analyzed.

[7] Measurements of other traces at Jungfraujoch are continuously performed by NABEL. NMHCs (n-pentane, iso-pentane, n-hexane, benzene and toluene) were measured with a GC-MS system optimized for the analysis of CFCs and HFCs [Reimann et al., 2004]. Nitrogen oxides (NO, $\mathrm{NO}_{2}$ and $\mathrm{NO}_{\mathrm{y}}$ ) were monitored with chemiluminescence detectors, carbon monoxide (CO) with nondispersive infrared technique (NDIR) and ozone $\left(\mathrm{O}_{3}\right)$ with $\mathrm{UV}$ absorption [Zellweger et al., 2000].

[8] In addition, formaldehyde has been measured using an instrument with the Hantzsch chemistry fluorimetric detection technique according to Junkermann and Burger [2006], a further development of the Aero Laser AL4021 [Hak et al., 2005]. The calibration was performed by using liquid standards (range 3-4 ppb), and the gas phase concentration was calculated from the enrichment factor between gas and liquid flows in the stripper. For more details see Balzani Lööv [2007].

\subsection{Filtering of Data}

[9] Meteorological processes were recognized as being important for understanding the abundance of the OVOCs and NMHCs at the site. The measurement data were therefore connected with meteorological information and trajectory analysis to identify the source regions of the air masses. The measurement data were first classified into either "undisturbed free tropospheric (FT) conditions" or "disturbed FT conditions." The term "disturbed FT" describes air masses that contain polluted boundary layer (PBL) air mixed with FT air during upward transport caused by different meteorological processes. Zellweger et al. [2003] estimated the contribution of PBL to undisturbed FT air masses to be $14-20 \%$ during convection events at Jungfraujoch. In the same paper it was suggested to use the $\mathrm{NO}_{\mathrm{y}} / \mathrm{CO}$ ratio to identify the undisturbed FT air masses. Recently, a similar approach was also applied by Zanis et al. [2006], when investigating the seasonal variability of the ozone production efficiencies in the lower free troposphere at Jungfraujoch, and by Walker et al. [2006], when studying 
the processes controlling the hydro peroxide concentrations at Jungfraujoch.

[10] In this study the $\mathrm{NO}_{\mathrm{y}} / \mathrm{CO}$ ratio applied for the filter was 0.005 (winter), 0.006 (spring and fall) and 0.007 (summer). The air masses with lower ratios were classified as undisturbed FT. Disturbed FT conditions were characterized by $\mathrm{NO}_{\mathrm{y}} / \mathrm{CO}$ ratios higher than 0.007 (winter), 0.008 (spring and fall) and 0.009 (summer). For the source estimation the data with $\mathrm{NO}_{\mathrm{y}} / \mathrm{CO}$ ratio between 0.005 and 0.007 (winter), 0.006 and 0.008 (spring and fall) and 0.007 and 0.009 (summer) were ignored. For the identification of source regions, aLMo (alpine model) 48-h backward trajectories were applied, which are described in more detail in the following paragraph.

\subsection{Source Identification by Backward Trajectory Model}

[11] Backward trajectories were calculated on the basis of the wind fields from the operational numerical weather prediction model (alpine model, aLMo) of the Federal Office of Meteorology and Climatology of Switzerland (MeteoSwiss). The aLMo runs on a horizontal $7 \mathrm{~km} \times$ $7 \mathrm{~km}$ grid and 45 vertical levels. Wind fields are available for each hour. $48 \mathrm{~h}$ backward trajectories are computed six times per day, every $4 \mathrm{~h}$. Their arrival point at Jungfraujoch is $100 \mathrm{~m}$ above model ground. To better account for complex flow regimes at the mountain site, additional four trajectories being displaced at the neighboring grid points were used together with the trajectory arriving at the exact location. For the data analysis these trajectories were combined with the measured data in order to identify source locations for the compounds. In this study we used the method of Seibert et al. [1994].

[12] The domain of the calculated trajectories was superimposed with a $0.22^{\circ} \times 0.22^{\circ}$ grid. The mean mixing ratio for these grid cells were calculated after the approach of Seibert et al. [1994] by the following formula:

$$
\overline{C_{m n}}=\frac{1}{\sum_{a=1}^{M} \tau_{m n a}} \sum_{a=1}^{M}\left(c_{a}\right) \tau_{m n a}
$$

where $\overline{C_{m n}}$ is a relative measure of potential source region strength, $\mathrm{m}, \mathrm{n}$ are indices of the horizontal grid, a is the index of the trajectory, $\mathrm{M}$ is the total number of trajectories, $\mathrm{c}_{\mathrm{a}}$ is the concentration (minus the background concentration) measured during arrival of trajectory a, and $\tau_{\text {mna }}$ is the residence time (in units of trajectory time steps) that the trajectory spent within the PBL over grid cell $\mathrm{m}, \mathrm{n}$. We assume a trajectory to reside within the PBL if the pressure difference between the trajectory and surface is smaller than $120 \mathrm{hPa}$ in winter and $200 \mathrm{hPa}$ in summer.

[13] A high $\overline{C_{m n}}$ value for a specific grid cell m,n means that overpassing air masses are on average associated with high mixing ratios at the receptor site. However, because of equal distributions of the measured mixing ratios to all grid cells passed by the appropriate trajectory, there is a possibility for underestimation of spatial gradients of true emissions [Stohl, 1996]. Other constraints are that by only measuring at one site the inhomogeneous advection regimes decrease the amount of independent information. The main influence region at Jungfraujoch is referred to as central western Europe (i.e., Switzerland, eastern France, southern Germany and northern Italy), which means that estimates from other parts of Europe are hindered by dilution processes during transport and low occurrence of transport from the respective area [Reimann et al., 2004].

\section{Results and Discussion}

\subsection{Description of Data}

[14] The mixing ratios of the measured OVOCs and NMHCs during the four campaigns at Jungfraujoch in 2005 are presented in Table 1 . The medians, means, interquartile ranges $(25-75)$ (IQR) for each compound as well as the detection limits ( $3 \sigma$ above noise) are listed for each compound. Because of ozone interference during the winter and spring campaign, the values for the impacted carbonyls (e.g., acetaldehyde and propanal) are not shown. In the following the measurement data from Jungfraujoch are compared with those of other studies from remote sites (Table 2) and the results are discussed in the context of known sources.

\subsubsection{Methyl-Tert-Butyl-Ether (MTBE) and NMHCs}

[15] MTBE and the aromatic NMHCs are atmospheric trace gases, which are exclusively emitted by anthropogenic sources. The average mixing ratio for MTBE was higher than from a background site in the USA (Trinidad Head) [Millet et al., 2004], which can be explained by the stronger influence of the polluted boundary layer at Jungfraujoch. Benzene was the most abundant NMHC with an IQR of 64-113 ppt in winter. In general, the NMHCs have higher mixing ratios in winter because of longer lifetimes in this season. However, the NMHCs are present in much lower mixing ratios than the OVOCs with less than $10 \%$ of the total measured organic compounds in summer and fall and less than $20 \%$ in winter and spring (although fewer aldehydes were measured in the winter and spring campaigns). 3.1.2. Esters

[16] To our knowledge, the first measurement results for esters at a background site are presented in this paper. Methyl and ethyl acetate were present at similar levels of about 5-30 ppt, whereas the mixing ratios of butyl acetate were mostly below 5 ppt. The esters are used as solvents in the industry, but can also be produced from the oxidation of alkenes with ozone [Atkinson, 2000]. They show high correlations during winter $\left(\mathrm{R}^{2}=0.64-0.87\right)$ indicating common sources. The good correlation of the esters with $\mathrm{CO}\left(\mathrm{R}^{2}=0.74-0.88\right)$ points to an anthropogenic origin related to well-mixed air from the polluted boundary layer. The correlation to $\mathrm{CO}$ was weaker in summer $(\mathrm{R}=0.23-$ 0.51 ), which most likely was due to photochemical production by the oxidation of alkenes.

\subsubsection{Alcohols}

[17] In agreement with the previous studies (Table 2), methanol was the alcohol with the highest mixing ratios. The IQR at Jungfraujoch in summer (597-956 ppt) was in between the values from the Arctic (256 ppt) and the values reported over the Pacific (1250 ppt), and in range of the measurements at the west coast of the USA (611-1021 ppt). In the European background air methanol values of about 600 to $2000 \mathrm{ppt}$ and 500 to $1500 \mathrm{ppt}$ were reported from an 
Table 1. Results From Four Seasonal Measurement Campaigns at Jungfraujoch in $2005^{\mathrm{a}}$

\begin{tabular}{|c|c|c|c|c|c|c|c|c|c|c|c|c|c|c|c|c|}
\hline \multirow{2}{*}{$\begin{array}{c}\text { Compounds (All Values } \\
\text { in ppt) }\end{array}$} & \multicolumn{4}{|c|}{ Spring 2005} & \multicolumn{4}{|c|}{ Summer 2005} & \multicolumn{4}{|c|}{ Fall 2005} & \multicolumn{4}{|c|}{ Winter 2005} \\
\hline & Median & Mean & $\mathrm{IQR}$ & Det.Limit & Median & Mean & $\mathrm{IQR}$ & Det.Limit & Median & Mean & $\mathrm{IQR}$ & Det.Limit & Median & Mean & IQR & Det.Limit \\
\hline Formaldehyde & 377 & 397 & $266-494$ & na & 466 & 505 & $359-574$ & na & 294 & 303 & $250-350$ & na & 268 & 362 & $171-537$ & na \\
\hline Acetaldehyde & na & na & na & na & 383 & 392 & $353-425$ & 70 & 310 & 310 & $292-331$ & 49 & na & na & na & na \\
\hline Propanal & na & na & na & na & 24 & 25 & $20-28$ & 11 & 20 & 21 & $17-24$ & 8 & na & na & na & na \\
\hline Butanal & na & na & na & na & 19 & 22 & $15-24$ & 4 & 23 & 24 & $18-29$ & 3 & na & na & na & na \\
\hline Pentanal & na & na & na & na & 10 & 11 & $9-12$ & 6 & 5 & 5 & $3-7$ & 9 & na & na & na & na \\
\hline Hexanal & na & na & na & na & 10 & 11 & $9-12$ & 6 & 9 & 10 & $8-12$ & 4 & na & na & na & na \\
\hline Benzaldehyde & 9 & 9 & $8-10$ & 2 & 4 & 4 & $3-6$ & 20 & 8 & 8 & $7-9$ & 12 & 3 & 4 & $2-5$ & 5 \\
\hline Acrolein & 15 & 16 & $13-17$ & 6 & 5 & 5 & $4-7$ & 5 & 3 & 3 & $2-3$ & 2 & 11 & 12 & $8-15$ & 9 \\
\hline Methacrolein & 3 & 3 & $2-3$ & 1 & 3 & 5 & $2-6$ & 2 & 1 & 2 & $1-2$ & 1 & 1 & 2 & $1-2$ & 2 \\
\hline Methyl-t-butyl-ether & 6 & 7 & $4-8$ & $<1$ & 6 & 8 & $4-10$ & $<1$ & 9 & 10 & $6-14$ & $<1$ & 7 & 8 & $4-12$ & $<1$ \\
\hline Acetone & 749 & 774 & $578-902$ & 24 & 862 & 867 & $718-991$ & 30 & 640 & 667 & $576-724$ & 47 & 560 & 622 & $487-749$ & 46 \\
\hline MVK & 8 & 10 & $6-12$ & 9 & 10 & 13 & $7-16$ & 5 & 4 & 4 & $3-5$ & 1 & 7 & 7 & $5-9$ & 10 \\
\hline MEK & 56 & 59 & $45-69$ & 1 & 35 & 37 & $24-47$ & 3 & 35 & 39 & $28-45$ & 1 & 83 & 101 & $63-135$ & 2 \\
\hline Methanol & 689 & 790 & $515-991$ & 62 & 747 & 769 & $579-956$ & 79 & 352 & 362 & $303-408$ & 66 & 482 & 550 & $402-657$ & 90 \\
\hline Ethanol & 122 & 135 & $76-174$ & 5 & 106 & 117 & $72-145$ & 7 & 194 & 206 & $157-232$ & 4 & 239 & 313 & $135-410$ & 72 \\
\hline Isopropanol & 24 & 28 & $19-32$ & 6 & na & na & na & na & na & na & na & na & 48 & 62 & $34-76$ & 13 \\
\hline Propanol & 4 & 4 & $3-5$ & $<1$ & 2 & 2 & $1-2$ & 5 & na & na & na & na & na & na & na-6 & 3 \\
\hline 2-Methyl-3-butene-2-ol & 7 & 9 & $7-11$ & $<1$ & 5 & 6 & $4-7$ & $<1$ & 3 & 4 & $3-4$ & $<1$ & 7 & 10 & $4-11$ & $<1$ \\
\hline Methyl acetate & 17 & 21 & $13-27$ & $<1$ & 13 & 13 & $11-15$ & $<1$ & 10 & 11 & $9-12$ & $<1$ & 14 & 18 & $12-24$ & $<1$ \\
\hline Ethyl acetate & 13 & 18 & $9-21$ & $<1$ & 8 & 9 & $6-11$ & $<1$ & 9 & 10 & $6-12$ & $<1$ & 17 & 22 & $11-31$ & $<1$ \\
\hline Butyl acetate & 4 & 4 & $3-5$ & $<1$ & 4 & 5 & $3-6$ & $<1$ & 4 & 5 & $3-5$ & $<1$ & 4 & 6 & $3-8$ & $<1$ \\
\hline Butane & 34 & 43 & $24-49$ & 5 & 26 & 31 & $18-39$ & 1 & 43 & 48 & $33-59$ & 1 & 187 & 209 & $132-252$ & 8 \\
\hline 1,3-Butadiene & 1 & 2 & $1-2$ & 1 & 1 & 1 & $1-1$ & $<1$ & 2 & 2 & $1-3$ & $<1$ & 1 & 2 & $1-4$ & $<1$ \\
\hline Isoprene & 1 & 1 & $0-1$ & $<1$ & 13 & 46 & $8-49$ & $<1$ & 8 & 13 & $7-13$ & $<1$ & 2 & 2 & $1-2$ & $<1$ \\
\hline Benzene & 23 & 25 & $17-29$ & 1 & 16 & 18 & $12-20$ & 1 & 20 & 21 & $16-24$ & $<1$ & 90 & 110 & $65-139$ & 1 \\
\hline Toluene & 59 & 70 & $42-81$ & 9 & 20 & 27 & $12-33$ & $<1$ & 58 & 62 & $44-71$ & 1 & 54 & 66 & $28-82$ & 5 \\
\hline Ethylbenzene & 16 & 18 & $12-22$ & 1 & 1 & 2 & $1-2$ & $<1$ & 2 & 2 & $2-3$ & $<1$ & 8 & 10 & $4-13$ & 2 \\
\hline $\mathrm{m}, \mathrm{p}$-Xylene & 67 & 75 & $51-100$ & 3 & 2 & 3 & $1-3$ & $<1$ & 5 & 6 & $4-7$ & $<1$ & 12 & 20 & $7-21$ & 6 \\
\hline o-Xylene & 5 & 7 & $3-8$ & 1 & 1 & 1 & $1-2$ & $<1$ & 2 & 2 & $2-2$ & $<1$ & 5 & 8 & $3-10$ & 3 \\
\hline
\end{tabular}

${ }^{\mathrm{a}}$ The medians, means, IQRs (interquartile ranges, 25-75) and detection limits for the OVOCs and NMHCs are listed. na, not available (see text for further explanation). 
Table 2. Overview of Previous OVOC Measurement Campaigns ${ }^{\text {a }}$

\begin{tabular}{|c|c|c|c|c|c|c|}
\hline $\begin{array}{c}\text { Compounds } \\
\text { (All Values in ppt) }\end{array}$ & $\begin{array}{l}\text { High Arctic 2000: } \\
\text { Mean } \pm \text { SD }\end{array}$ & $\begin{array}{l}\text { Trinidad Head, } \\
\text { USA 2002: IQR }\end{array}$ & $\begin{array}{l}\text { Pacific 2001: } \\
\text { Mean } \pm \text { SD }\end{array}$ & $\begin{array}{c}\text { Indian Ocean 1999: } \\
\text { Mean } \pm \text { SD }\end{array}$ & $\begin{array}{l}\text { Atlantic 1997: } \\
\text { Range }\end{array}$ & $\begin{array}{c}\text { Sonnblick } 1999 \\
\text { Range }\end{array}$ \\
\hline Formaldehyde & & & $188 \pm 133$ & & & \\
\hline Acetaldehyde & $166 \pm 79$ & & $226 \pm 89$ & $350 \pm 32$ & & \\
\hline Propanal & $11 \pm 5$ & & $77 \pm 34$ & & & \\
\hline Butanal & & $15-23$ & & & & \\
\hline Methacrolein & & $9-24$ & & & & \\
\hline Methyl-t-butyl-ether & & $1-6$ & & & & \\
\hline Acetone & $871 \pm 234$ & $529-801$ & $822 \pm 295$ & $1121 \pm 72$ & $630-920$ & $1500-3500$ \\
\hline 2-Butenone & & $3-9$ & & & & \\
\hline Butanone & $54 \pm 44$ & $45-76$ & $75 \pm 52$ & & & \\
\hline Methanol & $256 \pm 135$ & $611-1021$ & $1250 \pm 691$ & $687 \pm 106$ & $400-800$ & $800-2000$ \\
\hline Ethanol & $36 \pm 31$ & $75-168$ & $77 \pm 69$ & & $<50$ & \\
\hline Iso-propanol & & $11-27$ & & & & \\
\hline 2-Methyl-3-buten-2-ol & & $2-18$ & & & & \\
\hline Notes & $\begin{array}{l}\text { Apr-May (24 h } \\
\text { light period) }\end{array}$ & Apr-May & $\begin{array}{l}\text { Feb-Apr altitude: } \\
2-4 \mathrm{~km}\end{array}$ & Mar (NHcX flight) & Oct-Nov & fall/winter \\
\hline
\end{tabular}

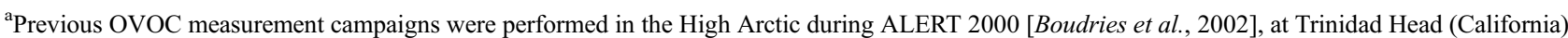
in 2002 [Millet et al., 2004], over the Pacific during TRACE-P in 2001 [Singh et al., 2004], over the Indian Ocean during INDOEX 1999 [Wisthaler et al., 2002], over the Atlantic in 1997 [Singh et al., 2000], and at Sonnblick, Austria in 1999 [Karl et al., 2001a].

aircraft campaign at $6 \mathrm{~km}$ altitude and at Mace Head, respectively [Colomb et al., 2006; Lewis et al., 2005]. The remote station at Mace Head is, depending on the wind direction, used to study the background marine air or European continental emissions. There are both anthropogenic and biogenic sources of methanol [Schade and Goldstein, 2006]. Biogenic sources of methanol have been summarized in a review by Fall [2003]. Furthermore, methanol is a secondary trace gas, and methane oxidation is postulated to be a substantial source as well [Jacob et al., 2005]. Evidence for secondary production of methanol in biomass burning plumes was reported by Holzinger et al. [2005] from aircraft measurements in southern Europe. Wisthaler et al. [2002] reported mean mixing ratios of methanol from 627 to 1417 ppt over the Indian ocean, depending on the origin of the air mass. Low mixing ratios were observed when the air mass arrived from the southern hemisphere, whereas elevated mixing ratios were seen in air from the continent. In this case also biomass burning was identified as a major source.

[18] Ethanol was present at Jungfraujoch at substantially lower levels than methanol, and had its highest mixing ratios in winter with an IQR of $135-410$ ppt. About $50 \%$ of ethanol in the background atmosphere over the Pacific was estimated to origin from primary biogenic sources [Singh et al., 2004]. Further, biomass burning, anthropogenic emissions and hydrocarbon oxidation were estimated to explain about 1/6 each. Ethanol at Jungfraujoch was in winter well correlated with $\mathrm{CO}$ in polluted air masses. Therefore it is assumed that a substantial part of the ethanol has been emitted by anthropogenic sources.

[19] In winter and spring, the average iso-propanol mixing ratio was $20 \%$ of that of ethanol. Sources for this compound are window cleaning fluids [Legreid et al., 2007] and industrial solvents. Propanol and 2-methyl-3buten-2-ol (MBO) are present at low ppt levels. MBO correlates well with MTBE $(\mathrm{R}=0.82)$ in summer providing evidence for anthropogenic sources, although the sources for $\mathrm{MBO}$ described in the literature have only been of biogenic origin [Schade and Goldstein, 2001].

\subsubsection{Ketones}

[20] Acetone was the most abundant OVOC measured at Jungfraujoch, showing only a moderate seasonal variation with an IQR of 718-991 ppt in summer and 487-749 ppt winter. These values are comparable to other studies in background atmospheres over the Pacific (822 ppt), from the Arctic (871 ppt), at the west coast of USA (529-801 ppt) and over the Indian Ocean (515-2080 ppt) (see Table 2). Similar values were also reported during a summer campaign at Mace Head [Lewis et al., 2005]. In general, mixing ratios of acetone are higher in continental air masses. Apart from its anthropogenic emissions from exhaust and solvent usage, acetone is reported to be emitted by biogenic sources [Fall, 2003; Poschl et al., 2001], biomass burning [Holzinger et al., 1999], and related to secondary production from MBO [Alvarado et al., 1999] or $\alpha$-pinene [Reissell et al., 1999]. Acetone has been shown to be a globally abundant compound which can act as a source of $\mathrm{HO}_{\mathrm{x}}$, peroxy and alkoxy radicals in the free troposphere [Arnold et al., 1997; Singh et al., 1994]. Jacob et al. [2002] estimated the oxidation of anthropogenic iso-alkanes to be the main source of acetone in the northern hemisphere in all seasons except summer. Terrestrial vegetation and oceans were identified as additional sources. The methanol/acetone ratio at Jungfraujoch varies from $\sim 0.5$ in fall to $\sim 1.0$ in spring, which is comparable to the study of Karl et al. [2001a] at Sonnblick in Austria (3100 m asl). It is lower than in a 1-year study of Schade and Goldstein [2006] at a rural site in USA with a measured methanol/acetone ratio of about 2 to 5 . This could be due to different source patterns between these substances in Europe compared to the USA. In the Arctic the ratio was as low as 0.3 under 24-h solar light conditions [Boudries et al., 2002], whereas the ratio was between 0.6 and 1.5 for other studies at remote sites (Table 2).

[21] Methyl ethyl ketone (MEK) was far less abundant than acetone with a mean mixing ratio of $101 \mathrm{ppt}$ in winter, which is in the range of the values reported from the west coast of the USA (45-76 ppt), the Arctic (55 ppt), and the Pacific (75 ppt) (see Table 2). The seasonal cycle was 
similar to benzene with higher mixing ratios in winter compared to summer, which implies dominant anthropogenic sources. MEK has several industrial sources [U.S. Environmental Protection Agency (U.S. EPA), 1994], but Riemer et al. [1998] also found evidence for biogenic sources of MEK from the good correlation of MEK with acetone and methanol in the absence of anthropogenic sources at a rural site in southeastern USA. At Jungfraujoch, MEK correlated well with acetone $(\mathrm{R}=0.83)$, methyl acetate $(\mathrm{R}=0.85)$, benzene $(\mathrm{R}=0.78)$ and butane $(\mathrm{R}=$ 0.73 ) in summer. The correlations with the solely anthropogenic emitted benzene and butane suggested significant contributions from anthropogenic sources.

\subsubsection{Aldehydes}

[22] Formaldehyde was the most abundant aldehyde at Jungfraujoch. Its seasonal cycle with a summer maximum (505 ppt) and lower mixing ratios in spring, fall and winter is explained by elevated photochemical production during the warm season. Grannas et al. [2002] reported an average mixing ratio of $166 \mathrm{ppt}$ in the Arctic boundary layer during sunlight conditions, and measurements performed from a ship in the southern Indian Ocean found $200 \pm 70 \mathrm{ppt}$ of formaldehyde [Wagner et al., 2002]. In the European remote marine boundary layer formaldehyde mixing ratios of 130$430 \mathrm{ppt}$ were found in summer [Still et al., 2006]. The higher mixing ratios at Jungfraujoch can be explained by the influence of the European boundary layer. Formaldehyde mixing ratios up to almost $1000 \mathrm{ppt}$ have been previously measured at the same altitude and latitude as Jungfraujoch during the aircraft campaign TOPSE 2000 [Fried et al., 2003]. Acetaldehyde was the second most abundant aldehyde found in this study, and it showed a summer maximum (IQR: 353-425 ppt) and lowest levels in fall (IQR: 292-331 ppt). These values are somewhat larger than reported from a study over the Pacific (226 $\pm 89 \mathrm{ppt})$ [Singh et al., 2004] and from the arctic (166 $\pm 79 \mathrm{ppt})$ [Boudries et al., 2002], probably because of the influence from the European boundary layer at Jungfraujoch. At Mace Head acetaldehyde values from about $150 \mathrm{ppt}$ to more than 2000 ppt were reported in summer [Lewis et al., 2005]. The high maximum value at Mace Head can be explained by local anthropogenic and biogenic sources. The observed values at Jungfraujoch were in the range of the mean values reported from the study over the Indian Ocean by Wisthaler et al. [2002] (178-424 ppt), where elevated acetaldehyde mixing ratios within continental air masses implied anthropogenic sources for this compound.

[23] The other aldehydes were present in much lower quantities decreasing with the length of the carbon chain. The propanal mixing ratios in this study were much lower (17-28 ppt), compared to values measured over the Pacific (77 ppt) [Singh et al., 2004], but were somewhat higher than those reported from the Artic (11 ppt) [Boudries et al., 2002]. Butanal was measured at the western coast of USA by Millet et al. [2004] in spring 2002 with an IQR of 15$23 \mathrm{ppt}$, which is almost identical to the summer values at Jungfraujoch (15-24 ppt). The unsaturated aldehydes acrolein and methacrolein were also present at Jungfraujoch in the lower ppt range $(2-17 \mathrm{ppt}$ and $2-6 \mathrm{ppt}$, respectively). Acrolein is mainly emitted by combustion of fossil fuel and had therefore higher mixing ratios in winter because of its longer lifetime and more stationary combustion during this season. Methacrolein is a secondary product from the oxidation of isoprene [Biesenthal et al., 1997] and was therefore more abundant in the summer season $(2-6 \mathrm{ppt})$ compared to winter $(1-2 \mathrm{ppt})$.

[24] The best correlation between the aldehydes was found for acetaldehyde and propanal $(\mathrm{R}=0.88)$ in summer, which was also the best correlation found under Artic conditions by Boudries et al. [2002] and over the Pacific [Singh et al., 2004]. This could imply similar sources and sinks for the two most abundant compounds among the aldehydes. Furthermore, acetaldehyde correlated also well with acrolein $(\mathrm{R}=0.81)$, acetone $(\mathrm{R}=0.80)$, MEK $(\mathrm{R}=$ $0.75)$ and methanol $(\mathrm{R}=0.69)$.

\subsection{Seasonal Variation}

[25] In Figure 1 the seasonal variation of selected VOCs are compared, showing noteworthy differences between the both primary and secondary OVOCs and the solely primary NMHCs. Several processes contribute to these differences. Benzene and butane have elevated mixing ratios in winter, which can be explained by their prolonged lifetime during this season. This is due to the lower mixing ratio of the $\mathrm{OH}$ radical, which is the main factor controlling the atmospheric destruction of these compounds. OVOCs have larger secondary and biogenic sources in summertime, which despite their lower lifetime during this season explains the higher mixing ratios. This trend was also observed at a rural station in California for methanol and acetone [Schade and Goldstein, 2006], but because of their local biogenic sources, their summer median was 5.5 times higher for methanol and 4 times higher for acetone compared to Jungfraujoch. At Jungfraujoch the summer median was $53 \%$ and $55 \%$ higher than in winter for methanol and acetone, respectively. In addition, the transport from the polluted boundary layer plays an important role, which is studied in more detail in the following.

\subsection{European Source Regions}

[26] Emissions from the European boundary layer contributed to the mixing ratios measured at Jungfraujoch during periods when polluted air masses are transported to the site by meteorological processes such as front passage and mountain venting [Henne et al., 2005]. In the following sections the potential source regions of the pollutants are investigated by the methods described in sections 2.2 and 2.3.

\subsubsection{From $\mathrm{CO} / \mathrm{NO}_{\mathrm{y}}$ Ratio and Visual Inspection of} Back Trajectories

[27] After separating the air masses into undisturbed and disturbed FT conditions (see section 2.2), the air masses qualified as disturbed FT conditions were further separated into northern, southern, eastern and western boundary layer origin by visual inspection of the calculated aLMo trajectories. In Figure 2 a time period in spring is shown, where the origin of the air mass is influenced by the southern boundary layer during 3 days (21.03-24.03). For FT conditions before and afterward the relative humidity and the $\mathrm{NO}_{\mathrm{y}} / \mathrm{CO}$ ratio was low, as well as the mixing ratios for all organic compounds. It was evident that high $\mathrm{NO}_{\mathrm{y}} / \mathrm{CO}$ ratios were useful indicators for boundary layer influence. In the morning of 21 May there is a rapid increase in the $\mathrm{NOy} / \mathrm{CO}$ ratio, which occurred concurrently with increasing 

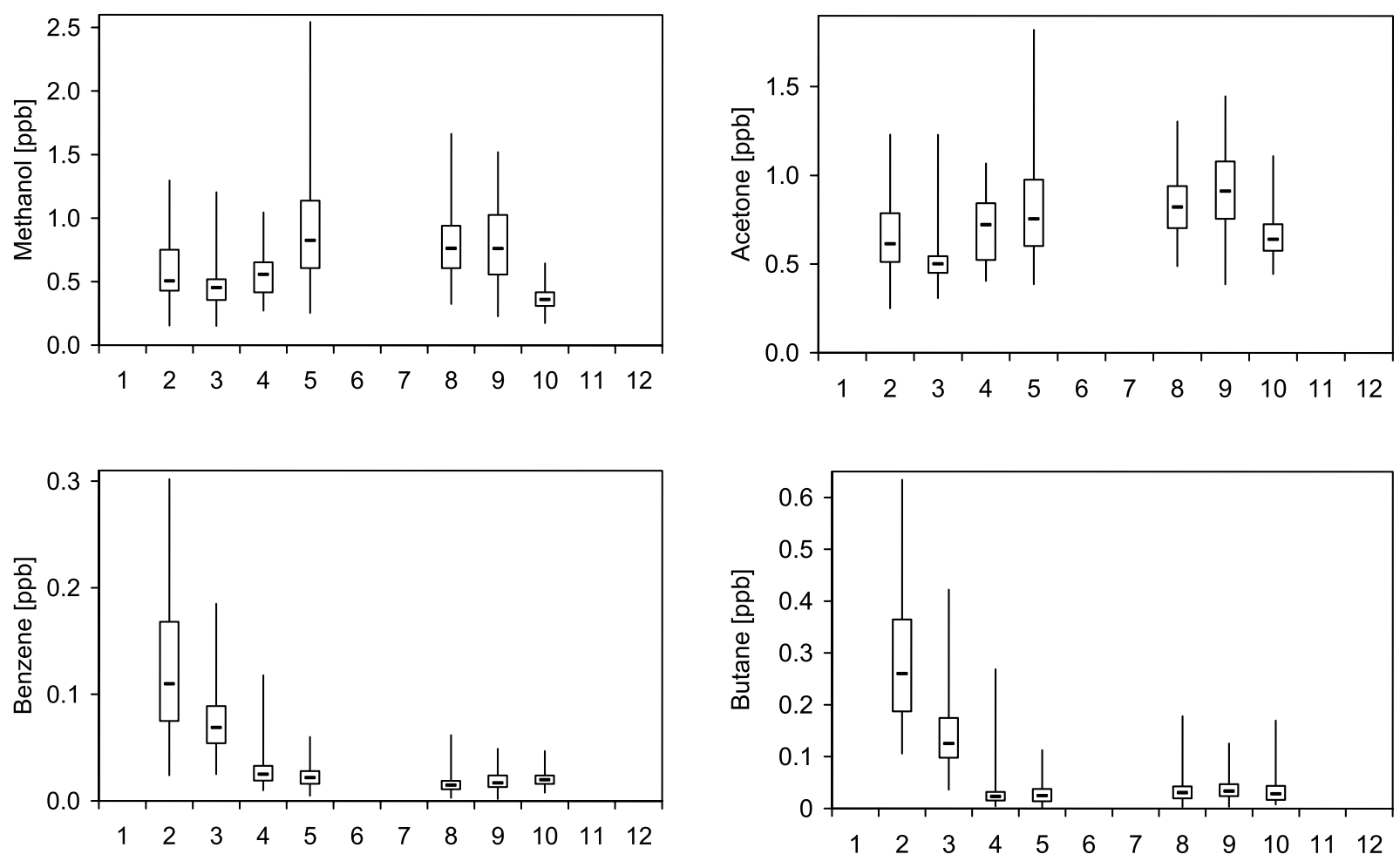

Figure 1. Monthly boxplots during the year 2005 at Jungfraujoch for the compounds methanol, acetone, benzene and butane. The numbers indicate the number of the Calendar months (i.e., 1 for January, 2 for February).
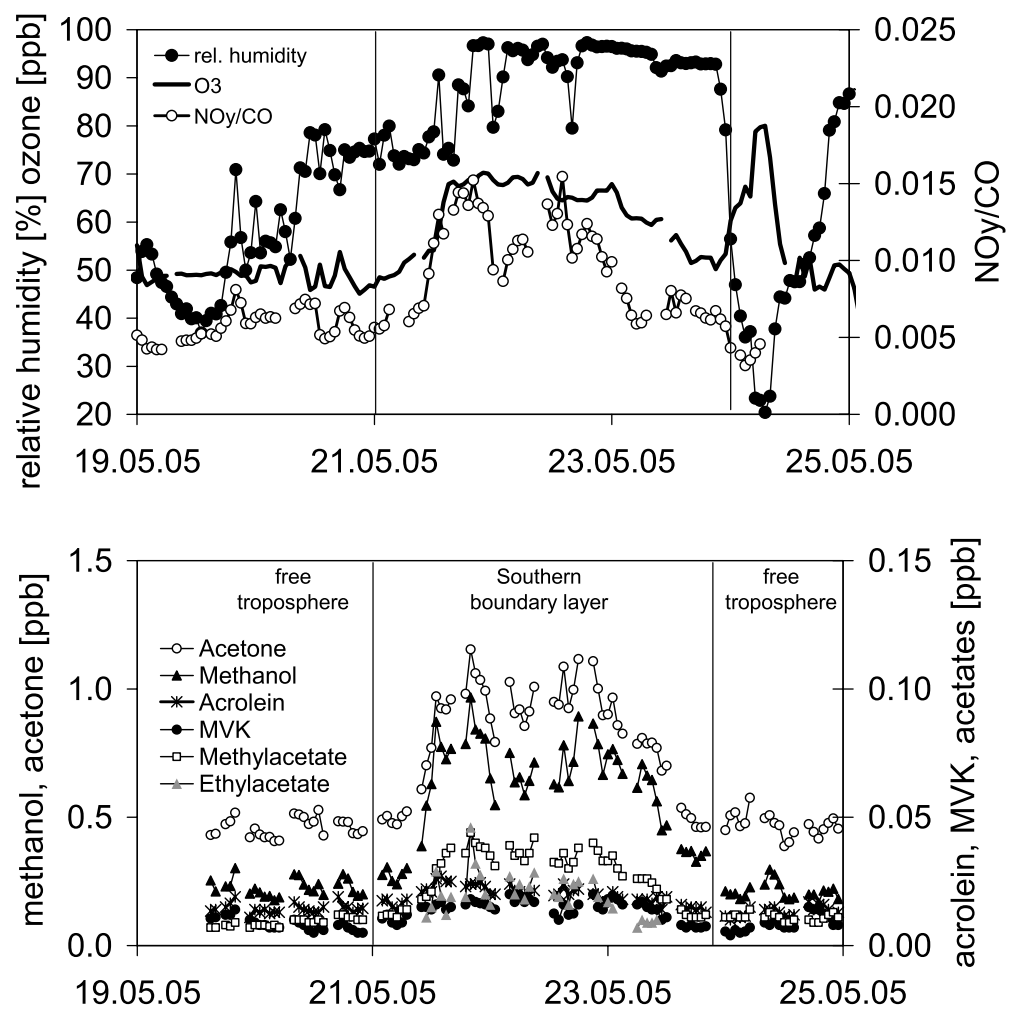

Figure 2. Time series of (top) relative humidity, $\mathrm{NO}_{\mathrm{y}} / \mathrm{CO}$ ratio and the mixing ratios of ozone and (bottom) acetone, methanol, acrolein, MVK, methyl acetate and ethyl acetate during $6 \mathrm{~d}$ in spring. 


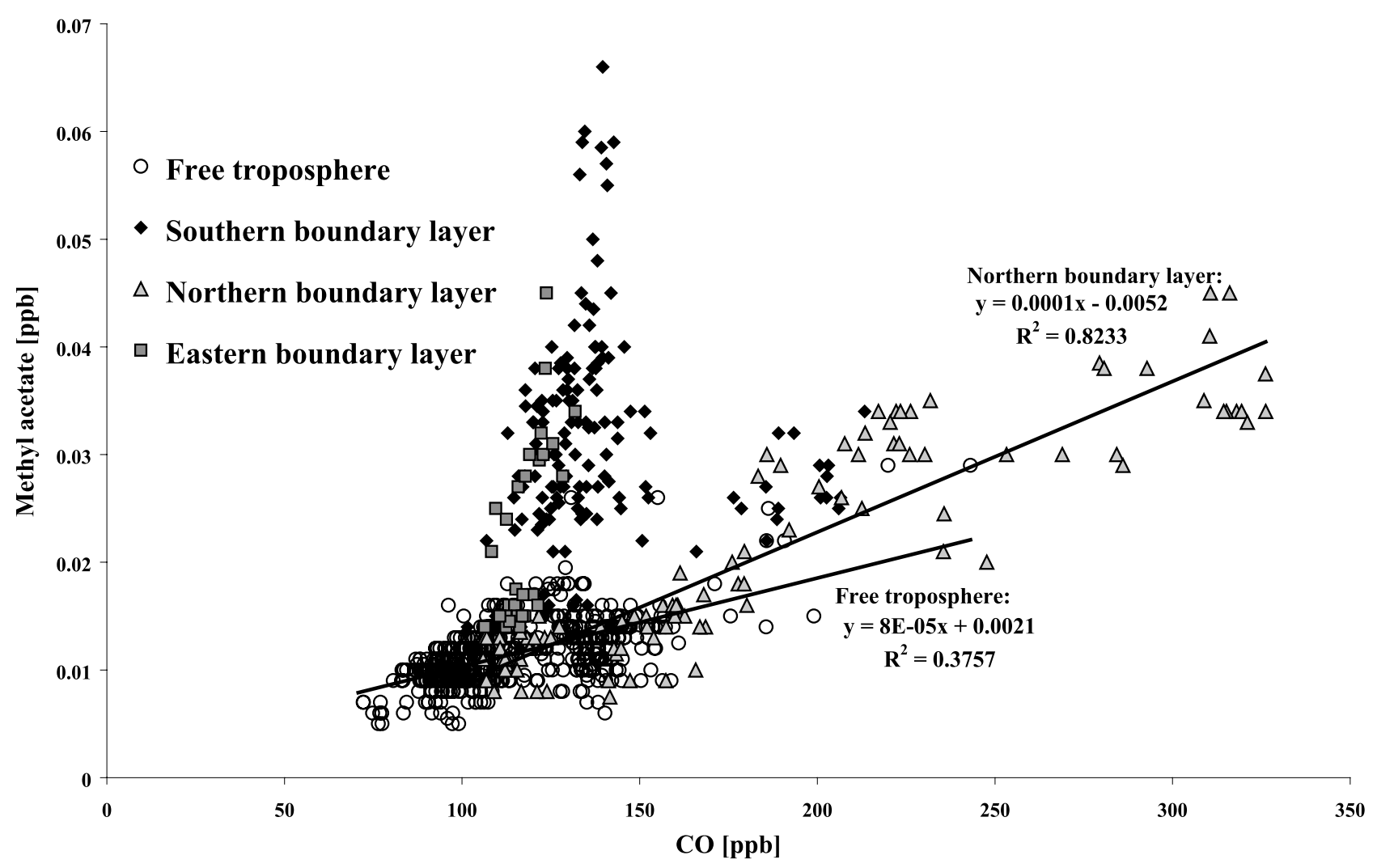

Figure 3. Methyl acetate correlation with CO separated into the source regions "Free troposphere" and northern, southern and eastern boundary layer for all data collected.

mixing ratios for ozone and the selected OVOCs. The relative humidity was also high during the period. The $\mathrm{NOy} / \mathrm{CO}$ ratio and the mixing ratios of ozone and OVOCs decreased in the night and early morning of 23 May as the air masses switched from boundary layer influence to free troposphere air. In the morning of 24 May, the relative humidity reached an unusually low minimum value concurrently with a peaking ozone mixing ratio. This can be explained by stratospheric air masses influencing the concentrations at Jungfraujoch during this event. However, the relatively small enhancement in ozone mixing ratio and the lack of simultaneous changes in the mixing ratios of the OVOCs showed that the stratospheric air was strongly mixed with free tropospheric air before reaching Jungfraujoch.

[28] Ratios of OVOCs against CO and other anthropogenic tracers have been used either for source allocations [Borbon et al., 2004; de Gouw et al., 2005] or for classification of air masses [De Reus et al., 2003]. For some compounds the ratio to $\mathrm{CO}$ was dependent on the origin of the air mass. Figure 3 shows mixing ratios of methyl acetate versus $\mathrm{CO}$ mixing ratios at Jungfraujoch for the complete set of data. The data representing northern boundary layer influence at the Jungfraujoch correlated well with $\mathrm{CO}$ and showed a $75 \%$ enhancement of the slope compared to the free tropospheric conditions. This might be due to emissions from the northern European boundary layer from the exhaust of fossil fuel burning processes. From the east and south there was strong evidence for additional sources not related to $\mathrm{CO}$ sources, which can be explained by the use of methyl acetate as an industrial solvent.

\subsubsection{From Statistical Trajectory Analysis}

[29] For a further distinction between European source regions of the OVOCs a more sophisticated approach was applied, which combined the measurement data at Jungfraujoch with statistical trajectory model (section 2.3). The measured concentrations of OVOCs with a lifetime of more than 3 days were combined with concurrent trajectories to retrieve a map of the European source regions. Because of the restricted representativity of the Jungfraujoch site (see section 2.3), the resulting pictures are biased toward central western Europe. They therefore only provide indications of potential source regions. Especially from France the source estimates could be underestimated because of the fact that if air masses are advected to Jungfraujoch from this region, transport is normally fast with low residence time within the boundary layer.

[30] The potential source regions of selected long-lived OVOCs are shown in Figure 4. The trajectory model shows a considerable contribution of methanol and acetone from the south. This seems to be reasonable since these compounds are emitted in large amounts from biogenic sources [Fall, 2003; Jacob et al., 2002, 2005; Singh et al., 1994], which because of the warmer climate are more active in the south of the Alps than in the north. The high contribution from northern Italy and southern France to the measured mixing ratios of methyl acetate and MEK can be explained by the high density of industry in these regions. Methyl acetate is used in glues and nail polish removers, in chemical reactions and for extractions (see Figure 4). MEK is a solvent used in the production of paints and 

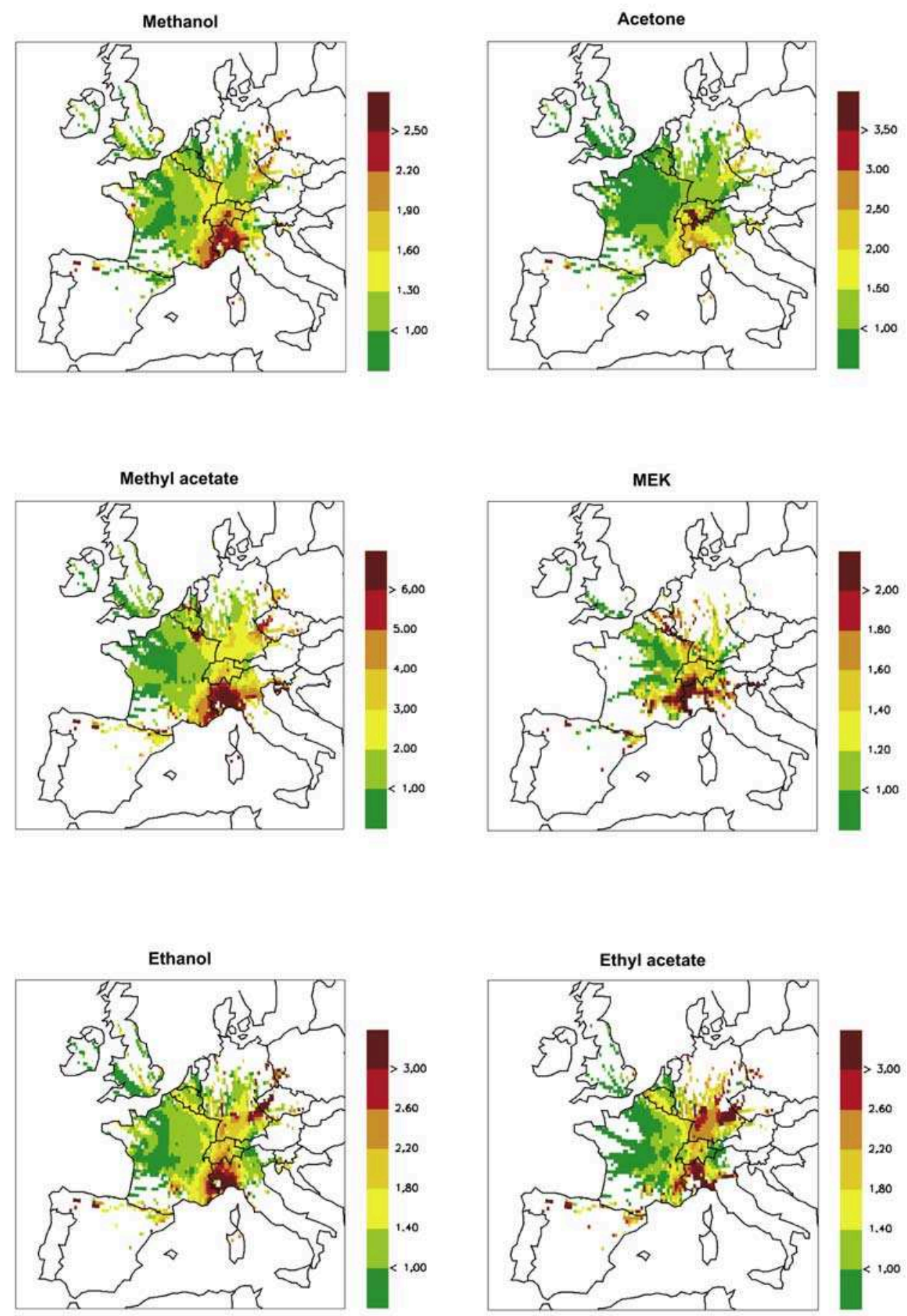

Figure 4. Map of potential source regions of methanol, acetone, methyl acetate, MEK, ethanol and ethyl acetate from about 4 months of measurement data, as determined by statistical trajectory analysis. Colors give relative importance of regions for measured above baseline mixing ratios at Jungfraujoch. Red colors indicate regions which are, on average, associated with high mixing ratios above baseline measured at Jungfraujoch. Green colors are associated with, on average, small above baseline mixing ratios at Jungfraujoch.

coatings [U.S. EPA, 1994]. In the case of ethanol and ethyl acetate there seem to be additional larger sources in Germany and Czech Republic. Ethanol is emitted from combustion sources, fermentation processes and from solvent use in the industry. Ethyl acetate is used in food production as and as a solvent in varnishes and paints.

[31] In Figure 5 the results from the trajectory statistics are shown for the two NMHCs butane and benzene. These 
Butane

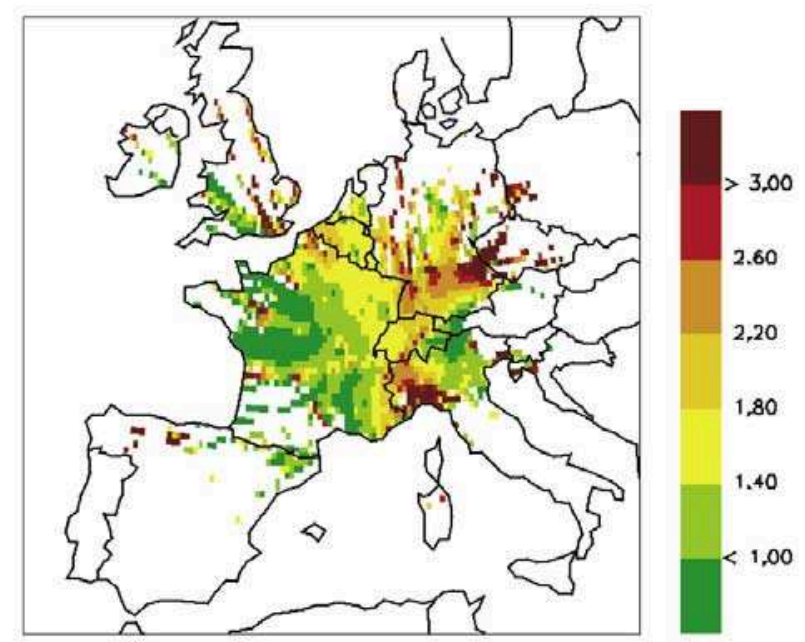

Benzene

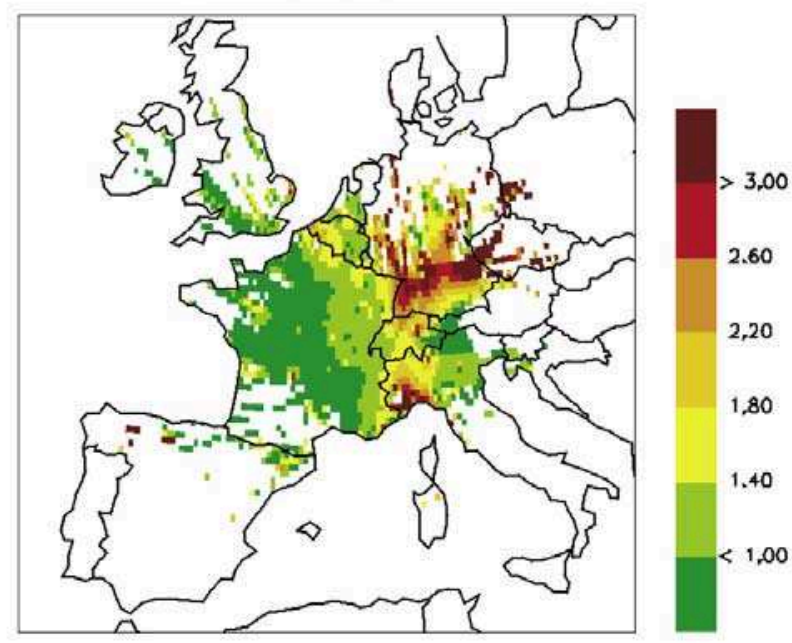

Figure 5. Map of potential source regions of butane and benzene from about 4 months of measurement data, as determined by statistical trajectory analysis. Colors give relative importance of regions for measured above baseline mixing ratios at Jungfraujoch. Red colors indicate regions which are, on average, associated with high mixing ratios above baseline measured at Jungfraujoch. Green colors are associated with, on average, small above baseline mixing ratios at Jungfraujoch.

NMHCs are indicators for anthropogenic sources, and they are at their highest levels when air masses are advected from Germany and from the northern part of Italy. This pattern is also in agreement with source regions identified from halocarbon measurements made at Jungfraujoch [Reimann et al., 2004]. There seems to be strong sources from eastern Germany and the Czech Republic as well, but because of the low number of trajectories from this region the uncertainty is high.

\section{Conclusions}

[32] Four seasonal measurements of OVOCs and selected NMHCs at the high alpine site of Jungfraujoch (Switzerland) have been presented. Most of the OVOCs had highest mixing ratios in summer because of higher emissions from biogenic sources and secondary oxidation processes. On the other hand, anthropogenic NMHCs were more elevated in winter, because of the longer lifetimes and more intensive stationary combustion during this season.

[33] Acetone, methanol, formaldehyde and acetaldehyde were the most abundant compounds measured at the high alpine station in all seasons, and were responsible for $95 \%$ of the measured VOCs in summer and $83 \%$ in fall. The measured mixing ratios of these compounds were similar to other studies from remote locations. For identification of source regions, a statistical approach using backward trajectories was applied. The anthropogenically emitted compounds butane, benzene, ethanol and ethyl acetate had two main source regions; southern Germany and northern Italy/ southern France, both heavily populated and industrialized areas. For the two industrial solvents methyl acetate and butanone (MEK) the main source region was solely northern Italy/southern France. Methanol and acetone, compounds which also have large biogenic sources, had their main contribution from the region south of the Alps as well.
This is probably due to the higher biogenic activity in this region compared to the north.

[34] Acknowledgments. This study was financially supported by the Swiss Federal Office for the Environment (FOEN/BAFU). For helpful discussions we thank P. G. Simmonds and D. Young at the University of Bristol. We thank MeteoSwiss for the preparation of meteorological data. We acknowledge the International Foundation High Altitude Research Stations Jungfraujoch and Gornergrat (HFSJG) for making our research possible at the High Altitude Research Station at Jungfraujoch. Last but not least, we thank the custodians at the Jungfraujoch, the Hemunds and the Fischers, for their enthusiasm and patience in supporting our activities.

\section{References}

Alvarado, A., et al. (1999), Products and mechanisms of the gas-phase reactions of $\mathrm{OH}$ radicals and O-3 with 2-methyl-3-buten-2-ol, Atmos. Environ., 33, 2893-2905.

Arnold, F., et al. (1997), Acetone in the upper troposphere and lower stratosphere: Impact on trace gases and aerosols, Geophys. Res. Lett., 24, $3017-3020$.

Atkinson, R. (2000), Atmospheric chemistry of VOCs and NOx, Atmos. Environ., 34, 2063-2101.

Balzani Lööv, J. M. (2007), Carbonyls and PANs at Jungfraujoch and the related oxidation processes at the boundary layer/free troposphere interface, thesis, ETH Zurich, Zurich, Switzerland.

Biesenthal, T. A., et al. (1997), A study of relationships between isoprene, its oxidation products, and ozone, in the Lower Fraser Valley, BC, Atmos. Environ., 31, 2049-2058.

Borbon, A., et al. (2004), Characterising sources and sinks of rural VOC in eastern France, Chemosphere, 57, 931-942.

Boudries, H., et al. (2002), Distribution and trends of oxygenated hydrocarbons in the high Arctic derived from measurements in the atmospheric boundary layer and interstitial snow air during the ALERT2000 field campaign, Atmos. Environ., 36, 2573-2583.

Colomb, A., et al. (2006), Airborne measurements of trace organic species in the upper troposphere over Europe: The impact of deep convection, Environ. Chem., 3, 244-259.

de Gouw, J. A., et al. (2005), Budget of organic carbon in a polluted atmosphere: Results from the New England Air Quality Study in 2002, J. Geophys. Res., 110, D16305, doi:10.1029/2004JD005623.

De Reus, M., et al. (2003), On the relationship between acetone and carbon monoxide in different air masses, Atmos. Chem. Phys., 3, 1709-1723.

Fall, R. (2003), Abundant oxygenates in the atmosphere: A biochemical perspective, Chem. Rev., 103, 4941-4951. 
Fried, A., et al. (2003), Airborne tunable diode laser measurements of formaldehyde during TRACE-P: Distributions and box model comparisons, J. Geophys. Res., 108(D20), 8798, doi:10.1029/2003JD003451.

Grannas, A. M., et al. (2002), A study of photochemical and physical processes affecting carbonyl compounds in the Arctic atmospheric boundary layer, Atmos. Environ., 36, 2733-2742.

Hak, C., et al. (2005), Intercomparison of four different in-situ techniques for ambient formaldehyde measurements in urban air, Atmos.Chem. Phys., 5, 2881-2900.

Henne, S., J. Dommen, B. Neininger, S. Reimann, J. Staehelin, and A. S. H. Prévôt (2005), Influence of mountain venting in the Alps on the ozone chemistry of the lower free troposphere and the European pollution export, J. Geophys. Res., 110, D22307, doi:10.1029/2005JD005936.

Holzinger, R., et al. (1999), Biomass burning as a source of formaldehyde, acetaldehyde, methanol, acetone, acetonitrile, and hydrogen cyanide, Geophys. Res. Lett., 26, 1161-1164.

Holzinger, R., et al. (2005), Oxygenated compounds in aged biomass burning plumes over the eastern Mediterranean: Evidence for strong secondary production of methanol and acetone, Atmos. Chem. Phys., 5, 39-46.

Jacob, D. J., B. D. Field, E. M. Jin, I. Bey, Q. Li, J. A. Logan, R. M. Yantosca, and H. B. Singh (2002), Atmospheric budget of acetone, J. Geophys. Res., 107(D10), 4100, doi:10.1029/2001JD000694.

Jacob, D. J., B. D. Field, Q. Li, D. R. Blake, J. de Gouw, C. Warneke, A. Hansel, A. Wisthaler, H. B. Singh, and A. Guenther (2005), Global budget of methanol: Constraints from atmospheric observations, J. Geophys. Res., 110, D08303, doi:10.1029/2004JD005172.

Junkermann, W., and J. M. Burger (2006), A new portable instrument for continuous measurement of formaldehyde in ambient air, J. Atmos. Oceanic Technol., 23, 38-45.

Karl, T., et al. (2001a), Variability-lifetime relationship of VOCs observed at the Sonnblick Observatory 1999-Estimation of HO-densities, Atmos. Environ., 35, 5287-5300.

Karl, T., et al. (2001b), High concentrations of reactive biogenic VOCs at a high altitude site in late autumn, Geophys. Res. Lett., 28, 507-510.

Komenda, M., et al. (2003), Description and characterization of an on-line system for long-term measurements of isoprene, methyl vinyl ketone, and methacrolein in ambient air, J. Chromatogr. A, 995, 185-201.

Legreid, G., J. Balzani Lööv, J. Staehelin, C. Hüglin, M. Hill, B. Buchmann, A. S. H. Prevot, and S. Reimann (2007), Oxygenated volatile organic compounds (OVOCs) at an urban background site in Zürich (Europe): Seasonal variation and source allocation, Atmos. Environ., 41, 8409-8423.

Lewis, A. C., et al. (2005), Sources and sinks of acetone, methanol, and acetaldehyde in North Atlantic air, Atmos. Chem. Phys., 5, 1285-1317.

Millet, D. B., et al. (2004), Volatile organic compound measurements at Trinidad Head, California, during ITCT 2K2: Analysis of sources, atmospheric composition, and aerosol residence times, J. Geophys. Res., 109, D23S16, doi:10.1029/2003JD004026.

Poschl, U., et al. (2001), High acetone concentrations throughout the 0$12 \mathrm{~km}$ altitude range over the tropical rainforest in Surinam, J. Atmos. Chem., 38, 115-132.

Reimann, S., D. Schaub, K. Stemmler, D. Folini, M. Hill, P. Hofer, B. Buchmann, P. G. Simmonds, B. R. Greally, and S. O'Doherty (2004), Halogenated greenhouse gases at the Swiss High Alpine Site of Jungfraujoch (3580 m asl): Continuous measurements and their use for regional European source allocation, J. Geophys. Res., 109, D05307, doi:10.1029/2003JD003923.

Reissell, A., et al. (1999), Formation of acetone from the $\mathrm{OH}$ radical- and O-3-initiated reactions of a series of monoterpenes, J. Geophys. Res. $104,13,869-13,879$

Riemer, D., et al. (1998), Observations of nonmethane hydrocarbons and oxygenated volatile organic compounds at a rural site in the southeastern United States, J. Geophys. Res., 103, 28,111-28,128.
Schade, G. W., and A. H. Goldstein (2001), Fluxes of oxygenated volatile organic compounds from a ponderosa pine plantation, J. Geophys. Res., 106, 3111-3123.

Schade, G. W., and A. H. Goldstein (2006), Seasonal measurements of acetone and methanol: Abundances and implications for atmospheric budgets, Global Biogeochem. Cycles, 20, GB1011, doi:10.1029/2005GB002566.

Seibert, P., H. Kromp-Kolb, U. Baltensperger, D. T. Jost, M. Schwikowski, A. Kasper, and H. Puxbaum (1994), Trajectory analysis of aerosol measurements at high alpine sites, in Transport and Transformation of Pollutants in the Troposphere, edited by P. M. Borrell et al., pp. 689-693, SPB Acad., The Hague, Netherlands.

Singh, H., et al. (2000), Distribution and fate of selected oxygenated organic species in the troposphere and lower stratosphere over the Atlantic, J. Geophys. Res., 105, 3795-3805.

Singh, H. B., et al. (1994), Acetone in the atmosphere: Distribution, sources, and sinks, J. Geophys. Res., 99, 1805-1819.

Singh, H. B., et al. (2004), Analysis of the atmospheric distribution, sources, and sinks of oxygenated volatile organic chemicals based on measurements over the Pacific during TRACE-P, J. Geophys. Res. 109, D15S07, doi:10.1029/2003JD003883.

Solberg, S., et al. (1996), Carbonyls and nonmethane hydrocarbons at rural European sites from the Mediterranean to the Arctic, J. Atmos. Chem., 25, $33-66$.

Still, T. J., et al. (2006), Ambient formaldehyde measurements made at a remote marine boundary layer site during the NAMBLEX campaign-A comparison of data from chromatographic and modified Hantzsch techniques, Atmos. Chem. Phys., 6, 2711-2726.

Stohl, A. (1996), Trajectory statistics - A new method to establish sourcereceptor relationships of air pollutants and its application to the transport of particulate sulfate in Europe, Atmos. Environ., 30, 579-587.

U.S. Environmental Protection Agency (1994), Locating and estimating air emissions from sources of methyl ethyl ketone, Rep. EPA-454/R-93-046, Off. of Air Qual. Plann. and Stand., Research Triangle Park, N. C.

Wagner, V., R. von Glasow, H. Fischer, and P. J. Crutzen (2002), Are $\mathrm{CH}_{2} \mathrm{O}$ measurements in the marine boundary layer suitable for testing the current understanding of $\mathrm{CH}_{4}$ photooxidation?: A model study, J. Geophys. Res., 107(D3), 4029, doi:10.1029/2001JD000722.

Walker, S. J., et al. (2006), Processes controlling the concentration of hydroperoxides at Jungfraujoch Observatory, Switzerland, Atmos. Chem. Phys., 6, 5525-5536.

Wennberg, P. O., et al. (1998), Hydrogen radicals, nitrogen radicals, and the production of $\mathrm{O}_{3}$ in the upper troposphere, Science, 279, 49-53.

Wisthaler, A., A. Hansel, R. R. Dickerson, and P. J. Crutzen (2002), Organic trace gas measurements by PTR-MS during INDOEX 1999, J. Geophys. Res., 107(D19), 8024, doi:10.1029/2001JD000576.

Zanis, P., et al. (2006), Seasonal variability of measured ozone production efficiencies in the lower free troposphere of central Europe, Atmos. Chem. Phys. Disc., 6, 9315-9349.

Zellweger, C., et al. (2000), Summertime NOy speciation at the Jungfraujoch, $3580 \mathrm{~m}$ above sea level, Switzerland, J. Geophys. Res., 105, 6655-6667.

Zellweger, C., et al. (2003), Partitioning of reactive nitrogen (NOy) and dependence on meteorological conditions in the lower free troposphere, Atmos. Chem. Phys., 3, 779-796.

D. Folini, G. Legreid, S. Reimann, and M. Steinbacher, Laboratory for Air Pollution and Environmental Technology, Swiss Federal Laboratories for Materials Testing and Research (EMPA), Ueberlandstrasse 129, CH8600 Duebendorf, Switzerland. (stefan.reimann@empa.ch)

J. Balzani Lööv and J. Staehelin, Institute for Atmospheric and Climate Science, Swiss Federal Institute of Technology, CH-8092 Zurich, Switzerland. 